\title{
The commodification of human reproductive materials
}

\author{
David B Resnik East Carolina University School of Medicine, Greenville, North Carolina, USA
}

\begin{abstract}
This essay develops a framework for thinking about the moral basis for the commodification of human reproductive materials. It argues that selling and buying gametes and genes is morally acceptable although there should not be a market for zygotes, embryos, or genomes. Also a market in gametes and genes should be regulated in order to address concerns about the adverse social consequences of commodification.

(Fournal of Medical Ethics 1998;24:388-393)
\end{abstract}

Keywords: Commodification; markets; gametes; zygotes; embryos; genomes; genes

\section{Introduction}

The burgeoning reproductive assistance industry has created an uneasy tension between individual economic interests and human dignity. On the one hand, people who donate sperm or eggs claim to have a right to remuneration for goods and services. If a person has a right to sell blood or hair, then that person should have a right to sell gametes. On the other hand, the commodification of tissues which have the potential to become adult human beings threatens human dignity and other moral values. Matters become even more complicated when we consider ownership of human genomes, since genomes are not simply pieces of tissue, but are blueprints for making and regulating organisms.

This essay develops a framework for thinking about the moral basis for a market in human reproductive materials. It argues that the commodification of gametes and genes is morally acceptable although there should not be a market for zygotes, embryos, or genomes. This position may be at odds with current property laws of many countries, which forbid the buying and selling of bodies and body parts, but the paper is concerned with moral, not legal issues. However, this essay may have some bearing on the morality of current or pending statutes, regulations, or court decisions.

\section{The moral basis for commodifying body parts}

Before turning to this paper's main topic, it will be useful discuss the moral basis for the commodification of body parts in general. Commodification is a social practice for treating things as commodi- $\omega_{\infty}$ ties, ie as properties that can be bought, sold, or rented. Since commodities are alienable - they can be sold - it is possible to regard something as a form of property but not as a commodity. Foro example, we might view voting rights as a type of property but not as a type of commodity, since voting rights may be acquired, lost, or owned, but not sold.

Even if we treat a thing as a commodity, we myẹ impose restrictions on its commerce for moral , ס social, economic, or political reasons. For exa푤 ple, condominiums are commodities that are bought, sold, and rented with various restriction pertaining to redecorating, pets, sub-leasing, pric $\frac{\pi}{\Omega}$ ing, etc. Thus, one may distinguish between two $\overrightarrow{0}$ forms of commodification: complete commodifi-3 cation (commodification with no restrictions) and? incomplete commodification (commodification? with restrictions). ${ }^{1}$ This distinction allows us to focus more clearly on this paper's main question $\bar{\Phi}$ should human reproductive materials be treated as complete commodities, incomplete commodities, or not as commodities at all?

The moral basis for treating these body parts or products as commodities stems from the body-asproperty view found in libertarian politicalo thought, which holds that the body and its parts may be bought, sold, and rented. This philosophyo traces its conceptual ancestry to the seventeenth 0 century philosopher John Locke, who argued that each individual's body belongs to that individual, and that individuals can acquire other propertieso by appropriating them from nature and mixing their labour with those things. ${ }^{2}$ This position? implies that individuals also own their body parts? and products. Locke's views on property still play? an important role in contemporary debates, and? modern libertarians have refined his position. ${ }^{3} \propto$

In the bioethics literature, several writers have defended the body-as-property view. ${ }^{4-7}$ According 
to Andrews, the principle of autonomy provides a basis for treating the body as property. ${ }^{4}$ Most of our autonomous choices presuppose some control over our own bodies. If we think of ownership of an object as a collection of rights to control the use of that object, then autonomous individuals own their bodies, body parts, and body products. Many of the most important standards in medical ethics also reflect this viewpoint. For example, invasive medical procedures require ethical justification. The very notion of an invasion of the body draws on the body-as-property image, since an invasion is an intrusion into a territory. The doctrine of informed consent also draws on the body-asproperty view. Informed consent holds that competent individuals have a right to exclusive control over their bodies, and exclusive control over an object is a characteristic of ownership.

For the purposes of this essay, I will accept the body-as-property view. I realise that this is a controversial position, but I will not defend it fully here. (I refer the reader to other authors for further discussion. ${ }^{4-7}$ ) Instead of defending this view, I will consider some arguments against commodification and use them to argue for incomplete commodification of the living body (I include the word "living" here to indicate that this discussion does not apply to cadavers, unless indicated otherwise.)

Why might one regard the body as commodity but resist its complete commodification? To answer this question it will be useful to address two important moral arguments against commodification. The first argument appeals to Kantian concerns about human dignity and personhood; the second examines the social consequences of ownership practices, attitudes, and policies. I will discuss these arguments in different contexts throughout this essay.

\section{Unconditional value}

According to the Kantian argument, commodification of the human body treats people as things that can be bought and sold. If human beings can be bought and sold, then they have a market value and can be treated as mere objects by themselves or other people. According to Kant, it is always wrong to treat people as mere objects, since human beings have inherent moral worth and dignity. ${ }^{8}$ Although objects can be treated as commodities and can be assigned a market value, human beings should not be treated as commodities and should not be assigned a market value. Human beings have an unconditional or absolute value. Thus, commodification of human beings is inherently wrong because it violates human dignity and worth. ${ }^{9}$
I accept this Kantian position. However, I think it is possible to treat human bodies as commodities without violating human dignity and worth. Although Kant uses the term "humanity" in describing our moral obligations, it is clear from reading his work that this term refers to the rational nature in human beings, ie "persons" or "rational agents". Kant recognised that the body houses many elements, such as emotions, physical desires, and so on, that are distinct from the body's rational nature. If we accept this separation of person and body, then one might commodify the body without treating a person as a commodity. Thus, bodies that do not contain persons, such as anencephalic newborns, bodies in a persistent vegetative state (PVS), or cadavers, could be commodified without violating the dignity or worth of persons.

\section{Unrealistic portrait}

However, this argument paints an unrealistic portrait of the connection between persons and bodies. The body is not like a coat that we can wear or a tool that we can use. Although it is possible to distinguish between the person and the body, these two entities are intimately connected in human beings. ${ }^{10}$ Selling a living human body is virtually the same thing as selling a person, and having exclusive control over someone else's body is tantamount to slavery. Only those who maintain a rigid mind/body dualism will not concede that there is an intimate relationship between the mind and body.

Yet this close connection only holds between the whole body and the person; it does not hold between parts (or products) of the body and the person. Although we think of persons as being connected to whole bodies, we do not think of persons as being tied to particular body parts or products. One does not lose a part of one's self by cutting one's hair, urinating, or donating blood. Thus, it is important to distinguish between a whole human body and its parts or products. Doing something to a part of the body does not imply doing something to the whole body, and selling a part (or product) of the body need not imply selling a whole body. Hence, one may commodify a part or product of the body without commodifying the whole body. (Some people view their personal identity as being closely connected to certain parts, such as the brain or heart, but this observation does not undermine my general point.)

With this distinction in mind, one might hold that parts of the body may be commodified even if the whole body should not be. Since the whole body is intimately connected to the person, it should not be viewed as alienable property. ${ }^{45}$ 
Hence, the whole body should not be treated as a complete commodity. But we can treat parts of the body as alienable even if the whole body should not be treated this way. Thus, one may hold that selling a whole body is immoral but regard commerce in human tissue as morally acceptable. However, there still may be some good reasons for regulating the sale of body parts. For instance, one might hold that it is immoral to sell body parts that are essential to the body's proper functioning because this form of commerce would imply murder, suicide, or other forms of killing. People may sell one kidney but not two kidneys, since human bodies cannot function without two kidneys. (A person might still give away his or her second kidney, but I will not address that question here.) Some organs, such as the heart and brain, may not be sold, given our current medical limitations and philosophical views about the connection between the person and the brain.

The second argument against treating bodies as commodities addresses slippery slope concerns: although it is not inherently wrong to sell body parts or products, the acceptance of this practice will lead to adverse social consequences as we move toward complete commodification of the body. ${ }^{1}$ According to Kass, if we allow body parts or products to be sold, then we will start to view the whole body as an object or commodity. This attitude will lead to the dehumanisation and objectification of people. ${ }^{9}$ Our downward slide might start with the selling of body parts, but it will lead to trade in children, anencephalic babies, cadavers, and PVS patients. Eventually we will sell adults into slavery. To preserve our belief in the inherent worth of human life and dignity, we must not view any part of the body as having commercial value.

While I appreciate the force of this argument, I think that we can avoid these adverse social consequences by regulating the market in body parts or products. ${ }^{4}$ We could forbid the sale of things whose commercialisation would have an adverse impact on our respect for human life and dignity, such as human cadavers, PVS bodies, anencephalic newborns, and so on. Informed consent would also seem to be a wise restriction on any commerce in body parts or products. By requiring that sellers and buyers give informed consent before a transaction takes place, we may be able to avoid many pitfalls. One of the biggest threats from a market in body parts comes when other people are allowed to treat a person's body as a commodity without that person's consent. ${ }^{4}$

Other writers object to commodification on the grounds that it undermines the gift relationship that currently exists between donors and recipients of human organs. A market in body parts and

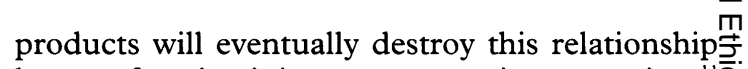
by transforming it into an economic transaction. ${ }^{11} \overline{\mathrm{C}}$. I do not find this argument very convincing since many commodities that are routinely bought and $\stackrel{\vec{s}}{?}$ sold are also given as gifts, such as clothing, land, cars, and labour. People will always have reasons흠 and motives for giving gifts, even when those gifts have commercial value. The mere fact that an object can be bought or sold need not destroy ouron ability to transfer that object as a gift.

Some writers have pointed out that commodify ing parts of the body might lead to a practices where people are required to sell body parts or products to pay outstanding debts or to meet the demands of retributive justice. ${ }^{5}$ Thus the phrase "it cost me an arm and a leg" would be too real too' invoke laughter. However, I think we can avoido these disturbing consequences if we enact some restrictions on the transference of body parts or? products. For instance, we could make it illegal to take body parts or products to pay debts or administer punishments.

Finally, one might argue that the selling of body? products could lead to the exploitation of the economically worse-off members of our society. Peg- $-\overrightarrow{0}$ ple might sell their kidneys out of econon $c^{\infty}$ hardship. ${ }^{19}$ But why would we think it is wrong sell body parts out of economic need? After all, people take on many dangerous and degradingo occupations for economic reasons. If it is wrong toő sell kidneys out of economic need, then it is also@ wrong to work in a coal mine or deliver pizzas in $\overrightarrow{\overrightarrow{0}}$ dangerous neighbourhoods. The problem with 3 working under these conditions is not the economic transaction itself; it is the fairness of the transaction. We have laws that protect people from exploitation and regulate working conditions: Similar laws could also apply to a market in body parts and products.

The preceding arguments against commodifi cation all suggest a common response: body partso and products, but not the whole body, should be regarded as incomplete commodities. In order too answer Kantians' concerns about the objectification of people, we should not permit a market in whole, living, human bodies; in order to address $N$ the slippery slope argument, we should regulate ${ }_{\mathrm{W}}^{N}$ the market in body parts and products. I will nowo apply this analysis to the commodification of human reproductive materials, paying special/ attention to the two main arguments against com $-?$ modification.

\section{The commodification of reproductive materials}

Is it immoral to buy and sell sperm, eggs, zygotes, embryos, or genomes? Before answering this 
question, it will be useful to distinguish between the sale of reproductive services (which is usually legal), and the sale of the reproductive materials themselves (which is often illegal). In the debate about surrogate mothering, some authors have argued that contracts with gestational surrogates are not baby-selling because these women are only selling the use of their wombs. ${ }^{12}$ Although I think this is an interesting distinction, I do not think it makes much sense for the issues that are the topic of this paper, since we are not dealing with forms of commodification that can be easily treated as mere services. Carrying a child in a womb is clearly a valuable service, but how is ejaculation a service? A donor who does not provide sperm will not be paid. The same point holds for other reproductive materials. Thus, this essay will focus only on the sale of reproductive materials.

\section{Commodification of gametes}

If it is morally acceptable to commodify body parts of products, then gametes may be bought and sold, since gametes are body products. If individuals can buy and sell blood, hair, or tissue, then they should also be allowed buy and sell gametes. ${ }^{13}$ However, the two arguments against commodification pertain to the sale of gametes. First, one might object to the commodification of gametes on the grounds that gametes are unlike other cells and tissues. Sperm and eggs contain half a human genome and can unite to form a zygote. A zygote can become a child if it implants in a uterus and develops normally. Thus, selling gametes is dangerously close to selling persons, since gametes can become persons. Although I agree that gametes (germ cells) are unlike other body cells (somatic cells), I do not find this argument very persuasive. Selling gametes is not the same thing as selling persons or zygotes, since gametes are not even potential persons. A gamete is more like half of a blueprint for making a house (person) than a whole blueprint (zygote) or house that is under construction (fetus or child).

Second, one might argue that the commodification of gametes will have adverse effects on other social values, such as our respect for human life and dignity. The commodification of gametes could create a market in children or adults, or it could lead to the exploitation of poor women for their eggs. For example, suppose that sperm are sold in fertility clinics and are advertised in magazines and newspapers. The market could set a price for gametes and those people with the "best" qualities could demand the highest prices for their reproductive materials. I think this type of development could threaten our notions of human dignity and worth; hence, we may need to regulate the market in gametes. Since the selling of gametes has not yet invaded our popular culture, this situation bears watching. In any case, this argument only shows that gametes should be treated as incomplete commodities.

\section{The commodification of zygotes and embryos}

One might also argue that zygotes and embryos (henceforth just zygotes) can be commodified on the grounds that they are simply body products. If gametes can be bought and sold, then zygotes can also be bought and sold. To make full sense of the objections to this argument, we must say something about when a human organism becomes a person, since the Kantian view forbids a market in persons but not a market in bodies, as such. If we follow the Kantian account of personhood, then a human being does not become a person until he or she can understand and follow moral imperatives. Thus, zygotes and other later stages of development are not persons. Kantian concerns about the objectification of persons therefore have little bearing on the selling of zygotes.

However, zygotes are potential persons. $\mathrm{Zy}-$ gotes, unlike gametes, have a complete set of genetic instructions and normally also have their own genetic identity. Although human development depends on many different environmental factors and gene-environment interactions, zygotes are much more like adult human beings than gametes. As potential persons, zygotes merit special moral concern. ${ }^{14}$ Potential persons merit special moral concern because the way we treat these beings can have a profound effect on the way we treat actual persons. A society that allows babies to be bought and sold is more likely to allow adults to be bought and sold than one that does not. Likewise, a society that allows zygotes to be bought and sold is more likely to accept a market for children and adults than one that does not. Moreover, this is not a problem that can be handled simply through regulation, since a market in zygotes would imply a profound change in our understanding of human beings and could lead to the commodification and objectification of children and adults. Since even a limited market for zygotes can create this dangerous slippery slope, zygotes should not be commodified. As an aside, this discussion has some bearing on disputes between couples over the use of frozen embryos. In one case, a woman wanted to implant a frozen embryo that she had produced with her estranged husband, but he refused to let her do this. ${ }^{15}$ Since frozen embryos should not be treated as commodities, this man should not be able to sell his 
rights to the embryo. Embryos also should not be traded for other items in divorce settlements. Although my view does not imply that embryos should not be treated as property, the slippery slope argument I have considered in this essay suggests that even allowing embryos to be treated as property could have some adverse consequences that we would want to avoid, such as baby-selling and the objectification of people. To avoid these consequences, the courts should treat embryos like children, not like commodities or other forms of property. The embryo's best interests, not market concerns or property rights, should play the deciding role in settling these cases.

\section{The commodification of genomes}

The last issue I would like to consider is the ownership of human genomes. To understand issues pertaining to the commodification of genomes and their parts (ie genes or gene fragments), it is important to realise that there is a fundamental difference between genomes, gametes, and zygotes. Gametes and zygotes are physical entities that can be produced, destroyed, corrupted, stored, or harvested; genomes and genes, on the other hand, are not mere physical entities. Gametes and zygotes have spatial-temporal boundaries; genomes and genes cannot be located in any particular time or place. Genomes and genes are essentially information for making and regulating organisms. ${ }^{16}$ As information, they constitute abstract objects that can be realised in biochemical structures or represented by linguistic symbols. They are more like software than hardware. In legalistic terms, genomes (and genes) are best viewed as intellectual property. ${ }^{1 .}$

Viewing the genome as intellectual property has important implications for moral arguments for and against its commodification. Western intellectual property laws distinguish between items that can belong to individuals and items that cannot be owned. For example, people cannot own scientific laws or concepts, though they may have copyrights over works that express those laws or concepts. People also cannot own natural phenomena, such as benzene, but they may patent processes for making benzene. The general thrust of these laws is to distinguish between ideas (or abstract objects) and tangible expressions or applications of those ideas. Ideas are common resources and cannot be owned by individuals, although particular expressions or applications of ideas can become personal property. ${ }^{18}$ Thus, these laws assume that only tangible expressions of ideas can be commodified.
There are two moral arguments for distinguish $-\frac{m}{5}$ ing between ideas and their expressions or applications. If we think of ideas as natural: resources, then Locke's views on property implys that ideas can be treated as common resources 0 People may own things that result from adding labour to those ideas, for example, inventions or? original works, but they may not own the ideasa themselves. According to the utilitarian approaches to intellectual property, intellectual property laws $\overrightarrow{0}$ should promote social utility through encouragingscientific and technological progress. The mostw effective way to promote this kind of progress is to encourage the sharing of ideas, data, and theoriesp while allowing scientists and inventors to profit from and receive credit for their works. Thus, there is a solid moral basis for laws that treat ideaso as common resources but allow the ownership of particular expressions or applications of ideas. ${ }^{19}$

I believe that the preceding discussion of intel $\vec{\square}$ lectual property can provide us with some insights into the commodification of human genomes. I we treat genomes as intellectual property, then genomes are natural phenomena. As such, they are common resources that may not be owneget although individuals may own particular expre sions or applications of genomes. If I invent technique for analysing, sequencing, or cloning genome (or one of its parts), then I may patento that invention; if I create an original work describ-气 ing a genome (or one of its parts), then I may have@ copyrights that govern the reproduction of that $\overrightarrow{\overrightarrow{0}}$ work. Hence, people may buy and sell inventions 3 and original works pertaining to the genome or genes, but they may not buy or sell naturally occurring genomes or genes.

Having said this much in favour of some form of ownership of the genome, I would like to address the two objections to commodification discussed previously. We can imagine some objectionable⿳̧冖 forms of ownership pertaining to the genome. Foro example, biotechnology companies have patented genetically engineered mice. What if a company attempted to patent a genetically engineered human being? Since patents govern the buying, selling, and production of inventions, this form of ownership would entail the ownership of persons since the patent would allow the company to con-o trol the production and marketing of wholeo human bodies. Copyrights on the whole genomed could result in similar problems. A person who? copyrighted an entire genome would be able to sell these copyrights to interested buyers. Al유 though this form of commerce would not? constitute commodification of a whole humano body, it could threaten our respect for human life and human dignity: a society that allows copies of 
genomes to be bought and sold is more likely to allow human beings to be bought and sold than one that does not. ${ }^{17}$ Selling copyrights to an entire genome is very much like selling a zygote, since genomes can be used to make zygotes.

On the other hand, patents and copyrights on parts of the genome would not entail the commodification of whole human bodies and probably would not threaten our respect for human life and human dignity. Patents or copyrights on individual genes would be no more pernicious than patents or copyrights on artificial body parts, such as artificial skin, blood, or heart valves. Thus, copyrights and patents can be extended to parts of the genome, but they should not be applied to the whole genome. However, there may be some good reasons to regulate the market in gene patents and copyrights in order to prevent slippery slope effects. For instance, we might choose to restrict the marketing of human genes used for the sole purpose of genetic engineering; we might forbid people or companies from acquiring a whole genome; we might take steps to prevent companies from obtaining monopolies on human genes, and so on. Hence, the entire human genome should not be regarded as a commodity, although parts of the genome may be regarded as incomplete commodities.

\section{Conclusion}

In this essay, I have argued that gametes and genes may be treated as incomplete commodities, while whole genomes, zygotes, and embryos should not be commodified at all. Markets in gametes and genes should also be regulated in order to prevent potential threats to human dignity and other moral values. I should note that this paper has not addressed other important questions pertaining to the ownership of human reproductive materials. Commodification simply represents a particular form of control, but other types of control are possible, such as stewardship, partnership, and so on. ${ }^{20}{ }^{21} \mathrm{~A}$ discussion of these other forms of ownership could provide some additional insights into proprietary relationships in human reproduction, but I will not engage these issues here.

\section{Acknowledgments}

A version of this paper was presented to audiences at the Department of Medical Humanities, East Carolina University School of Medicine, and the Department of Philosophy, University of South Carolina. The author is grateful to these audiences for helpful comments and discussions. The author also wishes to thank an anonymous reviewer from the fournal of Medical Ethics for useful criticisms.

David B Resnik, PhD, is Associate Professor, Department of Medical Humanities, East Carolina University School of Medicine, Greenville, North Carolina, USA.

\section{References}

1 Radin M. Contested commodities. Cambridge, MA: Harvard University Press, 1996.

2 Locke J. Second treatise of government. Macpherson C, ed. Indianapolis: Hackett, 1980.

3 Nozick R. Anarchy, state, and Utopia. New York: Basic Books, 1974.

4 Andrews L. My body, my property. Hastings Center Report 1986; 16,5: 28-38.

5 Campbell C. Body, self, and the property paradigm. Hastings Center Report 1992; 22,5: 34-42.

6 Scott R. The body as property. New York: Viking Press, 1981

7 Swain M, Marusyk R. An alternative to property rights in human tissue. Hastings Center Report 1990; 20,5: 12-15.

8 Kant I. Groundwork of the metaphysic of morals. [Translated by Paton H.] New York: Harper and Row, 1948.

9 Kass L. Organs for sale? Propriety, property, and the price of progress. The Public Interest 1992; 107: 76-82.

10 Bole T. Zygotes, souls, substances, and persons. Fournal of Medicine and Philosophy 1990; 15: 637-52.

11 Murray $T$. Who owns the body? On the ethics of using human tissue for commercial purposes. IRB: a review of human subjects research $1986 ; 8,1: 1-5$.

12 Steinbock B. Surrogate motherhood as prenatal adoption. Law, Medicine, and Health Care 1988; 16,1: 44-50.

13 Jansen R. Sperm and ova as property. Fournal of Medical Ethics 1985; 11,3: 123-6.

14 Callahan D. The puzzle of profound respect. Hastings Center Report 1995; 25,1: 39-40.

15 Davis v Davis, 1990 Tennessee Appellate LEXIS 642 (1990 Sept 13).

16 Mayr E. Cause and effect in biology. Science 1961; 134:1501-6.

17 Resnik D. The morality of human gene patents. Kennedy Institute of Ethics fournal 1997; 7,1: 43-61.

18 Foster F, Shook R. Patents, copyrights, and trademarks. New York: John Wiley and Sons, 1989.

19 Kuflik A. Moral foundations of intellectual property rights. In: Weil V, Snapper J, eds. Owning scientific and technical information. New Brunswick, NJ: Rutgers University Press, 1989.

20 Pretorius D. Rights to gametes, zygotes, and embryos in storage. Medical Law 1993; 12: 607-16.

21 Capron A. Parenthood and frozen embryos: more than property and privacy. Hastings Center Report 1992; 22,5: 32-3. 